\title{
Health Care Risk Waste Generated in Domestic Settings through Home Health: A Review of the Health and Environmental Impact in South Africa
}

\author{
T.S. Zikhathile and H.I. Atagana
}

\begin{abstract}
Significant amount of health care risk waste is generated in the process of home health. This waste poses serious threats to the health and the environment because it is infectious and hazardous in nature. It is responsible for the majority of reported injuries among waste workers and contaminating drinking water causing high prevalence of diarrheal diseases. It accounts for more than $\mathbf{1 0 \%}$ of the household waste and does not differ in composition and properties from the health care risk waste generated in health care facilities. It requires specific treatment and proper management prior to the disposal.

The study adopted a mixed research approach of collecting data. Health care risk waste generated in home health by home-based care givers was charecterised, sources identified and management practices investigated in the data collection. Results reveal that there is health care waste generated in home health. The generated health care risk waste is mixed with general household solid waste and managed in the same manner as domestic waste. The paper evaluates and analyses the potential impact of mismanagement of home generated health care risk waste on human health and the environment.
\end{abstract}

Keywords - Health care risk waste, home health, health, environment.

\section{INTRODUCTION}

Mismanagement of this waste may cause significant health impact and result in the environmental pollution and degradation. Even though it is generally known that health care facilities are the major generators of health care risk waste [1], which is where all the focus of regulating the management is concentrated. There is however significant amount of health care risk waste generated in homes by home-based care givers through home health [2-4]. It is therefore wrong to confine concerns of health care risk waste to health care facilities because based on ongoing research there is overwhelming evidence that health care risk waste is also generated in homes $[5,6]$. Research further suggest that health care risk waste generated in homes is the one that is increasing rapidly [7]. Furthermore health care risk waste generated in homes is

T.S. Zikhathile, Faculty of Natural Sciences, Mangosuthu University of Technology.

H.I. Atagana, Institute for Science and Technology Education, University of South Africa. growing considerably because there is now an increasing tendency for "hospital at home" $[8,9]$.

The burden of diseases has increased workload and causing challenge that is crippling the already fragile South African health system. This is because there an ever increasing demand for health services [10]. The health sector to experience a human resource crisis, among other problems as a result of increased workload. The government is battling to provide health services for all South Africans requiring it [11]. This has resulted in an increased demand of home health [12]. The health care risk waste generated in home health is however not accounted for [4].

\section{A. Definition and classification of health care risk waste}

The definition of health care risk waste to be managed and disposed varies widely for different countries and regions resulting in several different terms used to define and describe Health care risk waste [13]. The terms are 'Clinical waste', 'Health care waste', 'Infectious waste', 'Medical waste', 'Hospital waste', 'Health care risk waste', 'Biomedical waste', and 'Bio-hazard waste' [1, \& 14]. The term used in South Africa is Health care risk waste [15]. The terms used generally refer to materials generated as a result of patient diagnosis, treatment, or immunization of human beings or animals, and in research pertaining thereto, or testing of biologicals, including but not limited to soiled or blood-soaked bandages, culture dishes, and other glassware [16, 17]. Health care risk waste is defined as the wastes generated by health-care activities that can include a wide range of materials, such as used needles and syringes, soiled dressings, body parts, diagnostic samples, blood, chemicals, pharmaceuticals, medical devices and radioactive materials [14]. Discarded surgical gloves and instruments, lancets, cultures, stocks, and swabs used to inoculate cultures and removed body organs [17]

In the South African context, the term health care risk waste is used when referring to the waste generated when diagnosing and treating patients. Health care risk waste as the portion of the health care waste that is hazardous and including laboratory waste, anatomical waste, genotoxic / cytotoxic waste, infectious waste, sharps waste, sanitary waste, nappy waste, low-level radioactive waste, and pharmaceutical waste [15]. As a whole, the major components of health care risk waste include tissues, 
single-use disposable plastics, absorbent cottons, and pathological wastes [17]. Health care risk waste is waste that is infectious and hazardous hence it poses serious threats to environmental health because it contains highly toxic metals, toxic chemicals, pathogenic viruses and bacteria. [18]. That is why it requires specific treatment and management prior to its final disposal.

\section{B. Health care risk waste generation in home health}

The primary determining factor of the types and the quantities of health care risk waste generated depends on the type of services provided in home health [19]. A generator as any person, whose actions, or activities result in health care risk waste [15]. The Act further name the health care risk waste generators as follows: households; organisations; health care practitioners and health care facilities; veterinary practitioners, animal clinics, and animal hospitals; mortuaries, funeral parlours, undertakers and embalmers; emergency medical services; traditional healers; and tattoo artists and body piercers. However, the hospitals and clinics are the majority generators of health care risk waste because they provide the following services: Operating Theatres, Maternity ward, Accident \& Emergency, Mortuary, Intensive Care, Isolation Wards, Pharmacy, Pathology Laboratories and other research facilities [5]. The other sources of health care risk waste are ambulance services, public health laboratories, blood donation canters and blood banks, practice canter of doctors, dentists, veterinary surgeons, immunization/vaccination clinics and hospitals, clinics and nursing homes providing community care, care of the elderly and services related to mental health and learning disabilities.

Even though health care facilities are the major generators of health care risk waste, the minor generators such as homes cannot be ignored. Home generator is a household generator [15]. It is generators who generate less than 150 grams (excluding the container) per day of health care risk waste (excluding nappy waste), or less than 10 (ten) kilograms (excluding the container) per day of nappy waste, calculated monthly as a daily average. This excludes households or facilities which generate any sharps waste and who shall be considered a minor generator.

Homes in recent years have become a source of health care risk waste because of the hospital at home and establishment of home-based care. It has become a necessity to meet the health needs of the people and aid the overburdened health care system [19]. Medical devices and instruments are used by caregivers when treating patients at home, thereby producing a variety of waste materials [5]. Self-injecting diabetics and people changing colostomy bags at home also generate significant quantities of health care risk waste. In the United Kingdom the generated waste is estimated between 24,500 and 33,000 tons per annum [19]. In South Africa, the correct quantities of health care risk waste generated in domestic settings is not known. This is due to lack of research in this field, lack of health care risk waste knowledge by the generators, and unclear regulations on home generated health care risk waste. However, some researchers say there is an overwhelmingly large proportion of health care risk waste that arises from the domestic settings [3, 4]. The real argument is that the health care risk waste is very toxic and is ranked second most hazardous waste after radioactive waste [20], regardless of quantity. The practice of including generated health care risk waste with the domestic waste worsen the situation. The health care risk contaminates the domestic waste and escalated the quantity of health care risk waste [21]. As the health care risk waste joins the common municipal solid waste stream, and is disposed as general domestic. In the South African township context the majority of the waste generated is disposed of in landfill sites [27]. The other waste generated is discarded off in open fields by generators, the other is recycled [28]. This improper disposal process poses a serious health hazard to the general public, waste haulers, landfill personnel, and the environment [9].

The health care risk waste is generated during provision of nursing care [6].The generated waste is quite different. However, the most common is pharmaceutical waste and sharps [21]. The other waste is used bandages, dressings, swabs, blood, body fluids such as urine and salavia, urine, sanitary towels, human waste and feacal matter [4].

In the South African context, there is more health care risk waste generated in homes because of the number of people with chronic diseases and HIV/Aids [22]. It is estimated that Sub-Saharan Africa has the highest number of people living with HIV/Aids, and South Africa has the largest HIV/Aids epidemic worldwide with the prevalence of $19.2 \%$ [23].

The generated health care risk waste is collected in a mixed form, transported and disposed of along with municipal solid wastes [3]. Management of health care risk waste generated in home settings is an international problem and has increased in the past few years becoming a public concern [24]. The problem of mismanagement of health care risk waste is much severe in developing countries like South Africa [4]. It is estimated that over $45 \%$ of health care risk waste is unaccounted for and indiscriminately disposed in open fields [25]. The accurate estimate is not available because this is a fairly new field of research interest, but perceived to be much higher $[25,26]$. The public concern over mismanagement of health care risk waste is that the mismanagement of the waste is an environmental and health issue [29]. The waste has a potential of impacting the health of the general public that may be exposed to it, waste workers, waste scavengers, children, and public in general [30]. It also has a potential to cause pollution to the environment such as land, water, air, and wildlife [31]. Health care risk waste is considered to be very hazardous as it is ranked the second most hazardous after radioactive waste [20]

There are several unavoidable factors that contribute to the problem of mismanagement of the waste generated in homes. The problems are lack of infrastructure and resources to manage 
the waste in a proper manner. Lack of collaboration amongst government departments and sections within the Department of Health [26]. The department of Environmental Affairs is responsible for domestic waste management it however excludes Health Care Risk Waste generated in domestic settings [26]. The Department of Health through the Environmental Health closely monitor the health care risk waste generated in health care facilities but excludes health care risk waste generated in homes [4]. There is currently lack of policies and guidelines for health care risk waste generated in homes [4]. Lack of clear policies and guidelines for health care risk waste generated in homes means lack of defined procedures for proper management of the waste generated. Health care risk waste studies are insufficient, especially health care risk waste generated in homes through home health resulting in dearth of information. The South African government has not paid enough attention to the health care risk waste generated in homes through home health [26]. There is a lack of capacity for South African residents to adequately manage the generated health care risk waste generated in homes [4].

\section{METHODS}

This study used a mixed research method for collecting data. Data on health care risk waste generation and management was collected using questionnaires, interviews, and observation.

Questionnaires were distributed to the randomly selected home-based care givers to complete. The questionnaires were designed to collect information on home-based care, their patients, health care risk waste generation, and management of the generated health care risk waste.

Observation, the study participants were given $30 \times 50 \mathrm{~cm}$ plastic bags to collect health care risk waste generated on the day of data collection. The plastic bags were weighed using high resolution display glass scale measuring from $1 \mathrm{~g}$ to $5 \mathrm{~kg}$.

Interviews were conducted on managers of home-based care givers. Four interviews were conducted over six month's period.

A literature search was also 0performed by means of the 'Google search engine' for high impact papers on 'medical waste', based on the keywords: "health care waste", "home health", "home base care", "waste management", "HIV/AIDS" and "South Africa". The documents returned from these searches were used to identify narrower search terms, such as health care waste in domestic settings, medical waste in communities. Over fifty documents were retrieved (including some duplicates), out of which about twenty five were studied in detail. These included peer reviewed journal articles and conference proceedings, authentic book chapters, published and unpublished reports, and selected web references.

\section{STUDY PARTICIPANTS}

Study participants were generators of health care risk waste through home health, the home-based care giver and their managers. There were 219 home-based caregivers and two managers at the time of data collection. The study participants were employed by the Department of Health in Umlazi Township. The Statistical Package for the Social Sciences
(SPSS) method was used to calculate the sample size population for this research. The sample size was 80, and all 80 questionnaires were returned answered.

\section{RESUlTS}

Results are presented under the following themes: The home health activities that generate health care risk waste; Health care risk waste generated by home-based care givers in the process of home health; Management of health care risk waste generated by home-based care givers when proving home health services.

\section{A. Home health activities that generate health care risk waste}

The home health services provided by home-based care givers that generate health care risk waste include nursing care, physical care, patient support, and domestic chores. Nursing care is administering of medication, dressing of wounds, changing bandages, etc. The services that mostly generate health care risk waste are nursing care and physical care.

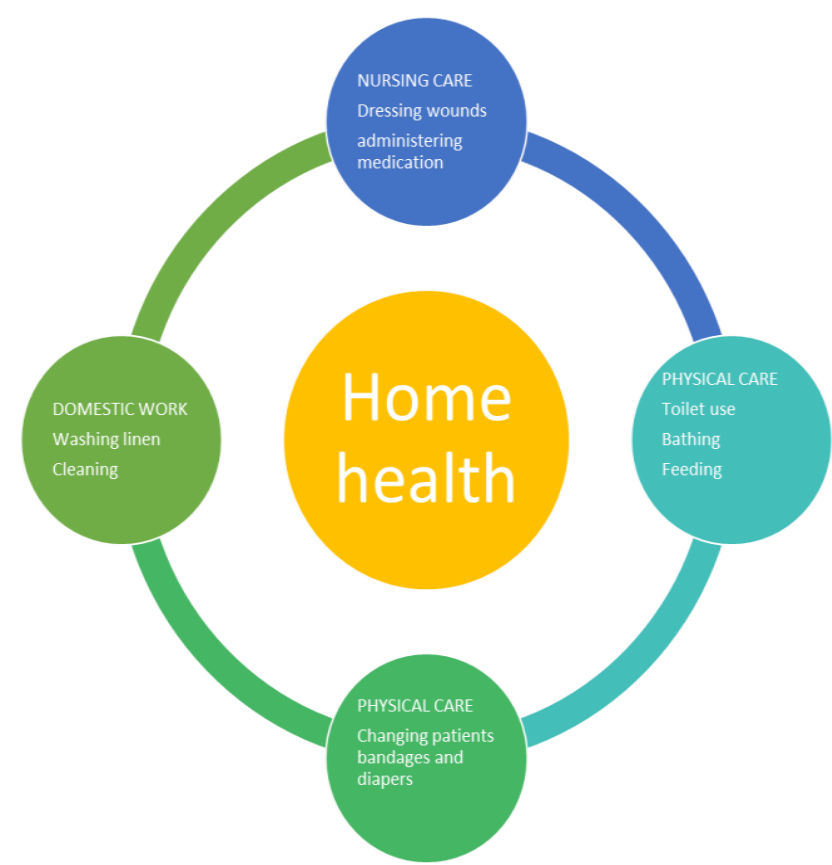

Fig 1: Home health activities that generate health care risk waste

\section{B. Work load}

The majority of the care givers on average visited a few houses on the day of data collection. Thirty-nine (39) and thirty-one (31) care givers visited three and four houses respectively. Four (4) visited up to five houses a day (Figure 2). 


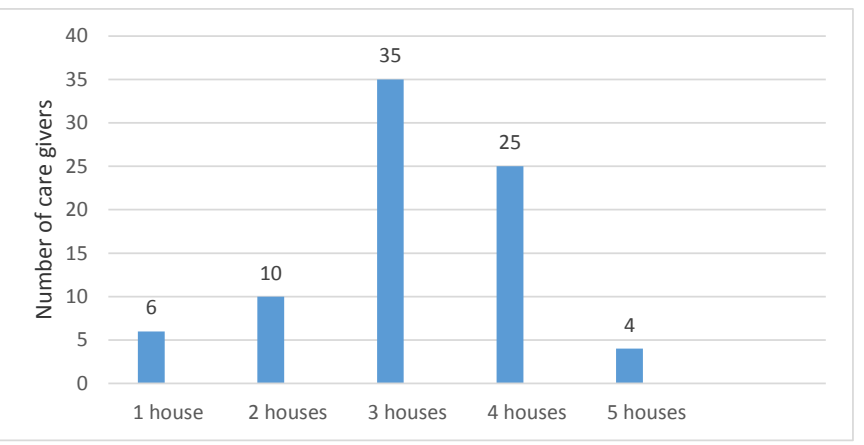

Figure 2: Number of houses visited by care givers a day

Fifty-one (51) care givers attended to one patient per household. However, some care givers attended to more than one patient per household. Four (4) care givers attended up to three patients per household nursing care (Figure 3).

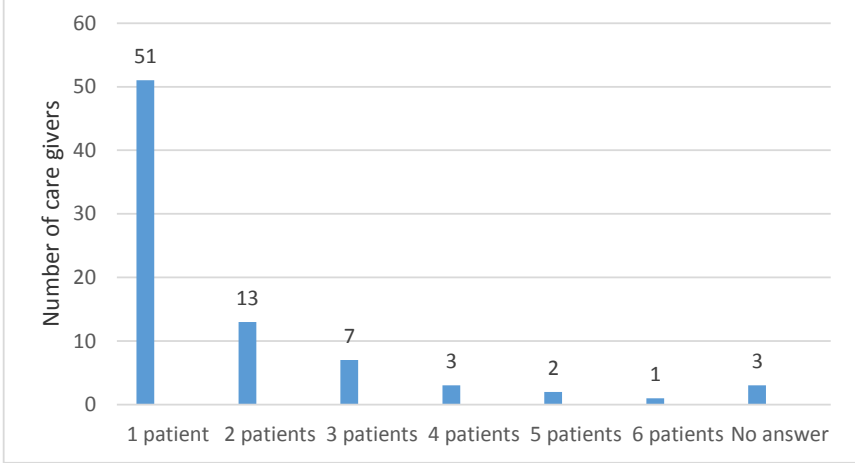

Figure 3: Number of patients attended to per household

\section{Health care risk waste generated}

The different types of health care risk waste generated in a day include used aprons, gloves, cotton, gauze, plasters, nappies, needles, syringes, toilet paper, medical containers, expired medication, human waste, vomit, sputum, pus, soiled linen, and plastic bags.

\section{Quantities of health care risk waste generated}

Plastic bags used to collect generated health care risk waste were approximately $32 \times 50 \mathrm{~cm}$ in size. Each plastic bag with health care risk waste of the day was weighed on a scale. The weight was rounded off to the nearest number to avoid decimals.

Thirteen (13) caregivers collected $0.5 \mathrm{~kg}$, thirty one (31) collected $1 \mathrm{~kg}$, twenty five (25) collected $2 \mathrm{~kg}$, nine (9) collected $3 \mathrm{~kg}$, and two (2) collected $4 \mathrm{~kg}$. Total amount of health care risk waste that was collected by home-based care givers on the day of data collection was $183.75 \mathrm{~kg}$. Therefore the average health care risk waste generated by home-based care givers is $2.3 \mathrm{~kg}$ a day.

\section{E. Management of health care risk waste}

The data collected indicates, that twenty two (22) caregivers leave the generated waste at the homestead where it was generated, nine (9) throw the waste anywhere deemed fit by them, eight (8) take the waste to the nearest health clinics to be disposed along with other health care waste, twenty (20) burn the waste, and nine flush or discard it in a pit latrine. The health care risk waste left in the household is either stored in plastic bags or general waste containers for approximately one week.

\section{DISCUSSION}

\section{A. Health care risk waste in home health}

Home health activities that generate health care risk waste nursing care, physical care, patient support, domestic chores, and psychological care. Nursing care includes dressing wounds, administering medication, and supervised treatment support (directly observed treatment support). Assisting patients to take their medication generates health care risk waste because the containers in which medication is kept are health care risk waste. Physical care includes assisting patients to use toilets, feeding and bathing patients, changing patients, and helping patients exercise. Domestic chores include collecting water for patients, and cleaning and washing for patients. There are other services offered by home-based care givers such as psychological care and support, however these services do not generate health care risk waste. The services that mostly generate health care risk waste are nursing care and physical care. Physical care includes bathing patients, feeding and assisting them to go to the toilet. The water used for bathing patients may be contaminated with either body secretions or blood resulting in the used water being health care risk waste. The materials used during nursing care such as bandages, cotton wool, and gauze are often contaminated with human secretions such as pus and blood. Nappies used by bedridden patients, and cotton wool and bandages used for treating wounds are health care risk waste, as are medication containers. Nappies used by bedridden patients, cotton wool and bandages used for treating wounds are also health care risk waste.

The care givers did not have sufficient knowledge of the appropriate health care risk waste management practices because they were not adequately trained. The only training offered to care givers is focused on nursing care, life skills, counseling, case-finding, and record-keeping. Lack of training causes care givers to be under-equipped in other aspects of health care such as infection control and, more importantly, the management of health care risk waste.

Results show that management of health care risk waste was not getting the attention it deserves because it was competing with other issues of home-based care for the very limited available resources. The health care risk waste was managed at the discretion of the generator, not according to legislation.

The appropriate practice is to take the generated health care risk waste to the nearest health care facility where the waste will enter the correct stream and be managed according to the regulations of the country. However, this practice faces financial and resource challenges as there is a growing number of people that require the services of care givers. The care givers are therefore left with the responsibility of managing an estimated $83 \%$ of the health care risk waste on their own. The majority of the generated waste enters the general waste stream. It was either disposed of by the local authority, thrown away at the discretion of the home owner, or taken by the care givers for disposal. This indicates lack of capacity by the Department of Health in dealing with health care risk waste and great negligence, as the waste was still handled and disposed of 
together with domestic wastes, thus creating a potential public health risk and an environmental burden.

\section{B. Impact of Health Care Risk Waste on health}

Almost all health care risk waste generated in homes is still included in general household waste in developing countries like South Africa [4]. This practice results in health care risk waste mismanagement. The mismanagement causes immense health challenges, which is a cause for concern because health care risk waste is infectious $[5,21]$. The health impact may be direct or indirect.

The direct impacts on health is through needle stick injuries, transmission of infectious agents [29]. The impacts may arise from collection, handling, transportation, treatment or the disposal of waste [3]. The health risks occur as a result of infection or injury mainly on healthcare workers, volunteer caregivers, and others who are involved in collecting, handling, transporting, or disposing of the wastes [29]. Needle-stick injuries has been reported to be the top three leading causes of injuries affecting waste workers [35]. Waste workers are injured when handling domestic waste.

The indirect impact on health is through environmental contamination. Health care risk waste such as faeces and urine

TABLE I. INFECTIONS CAUSED BY EXPOSURE TO HEALTH CARE RISK WASTES [33]

\begin{tabular}{|l|l|l|}
\hline Type of infection & Examples of causative organisms & Transmission vehicles \\
\hline Gastro enteric infections & $\begin{array}{l}\text { Enterobacteria, e.g. Salmonella, Shigella; } \\
\text { Vibrio cholera; helminths. }\end{array}$ & Faeces and/or vomit \\
\hline Respiratory infections & $\begin{array}{l}\text { Mycobacterium tuberculosis; measles } \\
\text { virus; Streptococcus pneumoniae }\end{array}$ & Inhaled secretions; saliva \\
\hline Ocular infection & Herpesvirus & Eye secretions \\
\hline Genital infections & Neisseria gonorrhoeae; herpesvirus & Genital secretions \\
\hline Skin infections & Streptococcus spp. & Pus \\
\hline Anthrax & Bacillus anthracis & Skin secretions \\
\hline Cerebrospinal fluid & Neisseria meningitides & Cerebrospinal fluid \\
\hline $\begin{array}{l}\text { Acquired immunodeficiency } \\
\text { AIDS) }\end{array}$ & Human immunodeficiency virus (HIV) & Blood, sexual secretions \\
\hline Haemorrhagic fevers & Junin, Lassa, Ebola, and Marburg viruses & All bloody products and secretions \\
\hline Septicaemia & Staphylococcus spp. & Blood \\
\hline Candidaemia & Candida albicans & Blood \\
\hline Viral hepatitis A & Hepatitis A virus & Faeces \\
\hline Viral hepatitis B and C & Hepatitis B and C viruses & Blood and body fluids \\
\hline
\end{tabular}
of health care risk waste mismanagement has been severe on the community and especially waste handlers in developing countries [34]. The impact is not acknowledged because of poor incident reporting and because there are not enough studies that have conducted in this area [21]. The little available information is on the municipal workers who often experience needle stick accidents when collecting or transporting domestic waste [35]. The available information on waste workers injuries is however not accurate [36]. Research indicate that some employees in almost all municipal governments have experienced needle stick accidents [5]. Recent studies on community acquired borne virus transmission attributed to on community acquired needle stick injuries [21]. All patients developed hepatitis, but no cases of HIV transmission have been reported. The reported
The World Health Organisation warns that the health impact needle stick injuries show that there have been reports of blood contain disease causing micro-organisms. If the health care risk waste is untreated, it may spread infection through contaminated water. People, animals, birds that scavenge at disposal sites may be infected [3]. Drinking of water contaminated by health care risk waste may cause diarrheal diseases [2]. Diarrheal diseases are a huge health challenge in South Africa [2]. It is estimated that contaminated water, inadequate sanitation and poor hygiene cause over $80 \%$ of all diseases in developing countries [21]. The most common diseases emanating from mismanagement of health care risk waste such as feaces and urine are dysentery, typhoid, bilharzia, malaria, cholera, parasitic worms [33]. Over and above the diseases that are caused by improper management of health care risk waste due to poor sanitation, there are diseases like HIV/AIDS, skin infection, infectious hepatitis that may spread within communities from infectious health care risk waste [1]. Mismanaged health care risk waste further provides suitable breeding ground for vectors which spread diseases. Examples of the potential infections caused by exposure to health care risk waste, their causative organisms, and transmission vehicles are illustrated in table 1 [33]. cases of Hepatitis B infection are from Spain, Tbilisi, Georgia, and Australia [21]

Children are also at risk to the adverse effects of health care risk waste mismanagement. Children are very curious and like role playing. There have been numerous reported incidents where children were found playing with health care risk waste both in the developing and developed countries [31]. Research further indicate that there have been numerous reports of children being poisoned by pharmaceutical health care risk waste [9]. There have been numerous incidents in South Africa where children were discovered playing with health care risk waste [37, 38]. This highlight the severity of the situation on mismanaging of Health Care Risk Waste in developing countries.

Another group of people that are negatively affected by improper management of health care risk waste are the waste pickers [35]. Some landfill sites in developing countries are big 
dump sites. They are not managed in a proper manner are not fenced off, and do not have poor security. This results in unwanted tip-face picking and scavenging [39]. Waste pickers collect waste from private waste bins, along the streets and waterways, communal dump sites, municipal dump sites, or landfills [40]. The high unemployment rate and poverty has driven people to scavenge. It is estimated that 15 million people in developing countries work as waste pickers and in South Africa 85,000 people make a living as waste pickers. [35]. Waste pickers collect, sort, and sell reusable and recyclable materials (such as paper, cardboard, plastic, glass, metal) primarily in an informal capacity [35].

\section{Impact of Health Care Risk Waste on the environment}

The failure to protect the environment from mismanagement of health care risk waste is a global problem faced by both developing and developed countries [1]. This has resulted in numerous concerns [41], such as prevention of pollution and protecting the environment [26]. Health care risk waste management practices in developing countries are quite poor and are dealt with much difficulty. This is because of poor environmental policies and organisational structures, poor funding, environmental problems such as widespread land degradation, desertification, loss of arable grazing land, declining soil productivity, loss of bio-diversity, water, land and air pollution, depletion of wetlands and freshwater resources, toxic waste and oil spillages dumped in water resources, poor sanitation and management of solid waste management [26]. The impact on the environment as a result of health care risk waste mismanagement have wider implications for food security and human health and impede the effort towards poverty eradication in the continent which is regarded as high priority [26]. The South African government has prioritized poverty and socio-economic needs and are seen as more pressing issues than the need for environmental controls [26]. Effectively, the neglect of the environment has a negative impact on socio-economic needs [26]. As a result, a wide range of environmental problems now affect our entire world. The earth's natural processes transform local problems into international issues hence the global concern of health care risk waste mismanagement [26].

As it the common practice in South Africa to manage health care risk waste in the same manner as domestic waste [36]; this means it enters normal domestic waste stream and disposed in a landfill site for the areas with waste removal services [42]. All waste taken to the disposal sites is not treated before disposal. It is buried in the ground with domestic waste [21]. The buried waste form leachate. Leachate is a liquid that drains from a landfill site caused by precipitation seeping into landfilled waste [21]. The leachate generated flows directly to the ground water and other water sources and cause water pollution [21].

Some areas in South Africa do not have waste removal and sanitation services [4]. Generated health care risk waste is therefore disposed at the discretion of the generator [4]. The general practice for those who do have waste removal services is burning of the generated health care risk waste [21]. This practice has severe consequences on the environment as it causes environmental pollution by the release of toxic air emissions [21]. Also, burning plastics that are widely used for disposable materials and chlorinated materials are major sources of dioxins. Dioxins are a common term for chemical compounds consisting of chlorinated dibenzo-furans and dibenzo-dioxins known to be toxic and to have carcinogenic potential [21]. Burning health care risk waste contribute to the climatic issues caused by global warming. Waste incineration may also cause respiratory infections when ash particles are deposited into the environment and inhaled by people [21].

Some areas do not have proper sanitation facilities resulting in the generated liquid health care risk waste such as human excreta and urine to be disposed in an unsafe manner. The disposal practices contaminate the surrounding environment [3]. The generators are therefore unable to dispose human excreta and liquid Health Care Risk Waste in a safe and dignified manner. This health care risk waste is generally disposed in shallow graves that get washed off during heavy rains and contaminate ground water and water sources or in open fields [2].

Landfill disposal of untreated health care risk waste results in leaching of toxic metals and chemicals into the soil in poorly engineered landfills and open dump sites [21]. The toxic materials and the chemicals are ultimately absorbed in the food chain and consumed by man as man is at the top of the food chain [21]. In addition, leachate can percolate through the soil and contaminate surface and groundwater supplies posing threats to human health by consumption of unsafe water [21]. It is warned that the contribution of leachate generated from health care risk waste emanating from home health can be considered minimal relative to health care risk waste from hospitals [21]. However, it still poses a potential hazard to the environment and human health.

Health Care Risk Waste management is not an isolated or new problem in South Africa [4]. South Africa has a poor environmental management record, manifesting in industrial pollution, mining waste, chemical waste, acid rain and water pollution, which affects the livelihoods and health of workers and surrounding communities [26]. Effectively, the crisis of Health Care Risk Waste management poses additional challenges to the South African environment that is already massively afflicted by these and other environmental problems [26].

\section{Other issues arising from Health Care Risk Waste mismanagement}

The irresponsible and illegal disposal of home generated health care risk waste places an unacceptably high financial and human resources burden on the South African government to manage the problem [43]. The environmental justice movements say that the practice of health care risk waste mismanagement economically and socially disadvantage communities that are already poor [43]. The economically and socially disadvantaged communities are the non-white, poor, less educated, and politically less powerful [44]. This is the 
previously disadvantaged group. These are the people that are already burdened by disease such as HIV/AIDS and opportunistic infections [44].

\section{E. Challenges of Health Care Risk Waste management}

The absence of proper procedure in place of home generated health care risk waste in is the driving force behind mismanagement [21]. Even the management of domestic waste differs considerably in South Africa. Management of domestic waste is motivated by the availability of waste management resources, practicality, and accessibility [4]. The divisions of the apartheid era is largely to blame for the difference in the provision of waste services. South Africa has urban and rural areas. Within the urban areas, there are formal and informal settlements. Waste emanating from urban formal settlements is collected the municipality or by a private contractors on behalf of the municipality [45]. Waste emanating from the urban informal settlements is taken by the generator to a common waste collection point [45]. There are waste receptors for the community to dispose of the waste. There are huge challenges with these community receptors. The community members do not always place the waste inside, but place the waste around the receptors [45]. The collection of the waste is ad hoc and sometimes the waste is left for months. Waste emanating from rural areas is disposed at the discretion of the generator [45]. It is either thrown in an open dump, incinerated, or buried. General waste from urban formal settlements is commonly disposed of two ways. It is either channeled towards the municipal waste stream, where the municipality or a private company contracted by the municipality disposes the waste; or it is disposed of at the discretion of the residents by incinerating or dumping it anyhow [45].

The practice of carrying health care risk waste is difficult for the community. They do not have appropriate containers to conceal the health care risk waste. Health care facilities are sometimes far from the community and becomes difficult for people to carry the waste for long distances.

South Africa is further challenged by inadequate sanitation facilities. Lack of sanitation facilities results in the ordinary human waste and domestic waste not to be disposed in a correct manner. The human waste is disposed in open spaces [4]. The absence of sanitation facility also mean that waste water contaminated by health care risk waste is disposed in an incorrect manner. The waste water is normally discarded in the back yards [3]. Some of the home generated health care risk waste is incinerated using firewood to maintain better hygiene practices [2]. However, in recent years the practice of incinerating has been becoming difficult because it increasingly becoming difficult to obtain firewood people have to travel long distance to obtain firewood [2].

\section{F. Proposed Health Care Risk Waste management practices}

It is the responsibility of health care risk waste generator to ensure correct management of the waste generated [46]. South Africa can model the behavior of the developed countries in terms of management of health care risk waste generated in homes. The South African government can start by prohibiting mismanagement of health care risk waste generated in homes. Some countries enforce the generator of health care risk waste to purchase sharps container or a heavy-plastic container [24]. The South African government can make it a law that all households must have sharp containers. The communities that go to private health care facilities can be required to buy the containers and the communities that go public health care facilities can be given the containers by the government.

Another alternative could be home doctors or care givers to carry sharps containers and collect the health care risk waste after generation and the waste to be taken to their organizations [6]. Other alternative method that can be used is for patients receiving care from home-based care take the generated health care risk waste to the nearest hospital or pharmacy. Another is health care risk waste to be taken to collection sites, disposal kiosks, or return health care risk waste by mail boxes [5-7]. Another is to have hospitals and community health centres operate take-back schemes where patients deliver health care risk waste for disposal as it is done the developed countries [6].

In Japan, health care risk waste generated at home is either collected by home-based care giver or collected by local municipality to be treated before disposal [6]. The patients are responsible for storing the generated waste until it is collected by the local municipality. If the waste is not collected by the local municipality, then the patients are required to take the waste to the hospital or pharmacy [6]. The South African governments can equip and educate municipal waste workers and care givers to manage health care risk waste in a safe manner.

More research on health care risk waste is essential, especially health care risk waste from home health. The research can identify current gaps in the legislation, give accurate health and environmental impact of the mismanagement of health care risk waste, and will allow for future planning and correct resources allocation.

\section{CONCLUSION}

It is without a doubt that there is health care risk waste generated in homes and quantities is rapidly increasing and it is a global issue. There needs to great emphasis placed on the management of this waste. This is because mismanagement of this waste is linked to numerous high health and environmental threats. It is also a violation of environmental and health laws

The health and environmental impact that mismanagement of health care risk waste may be identified, however the impact is far devastating than what is revealed. Therefore, management of home generated health care risk waste should be a priority. Delivering and improving health care risk waste management services for home generated health care risk waste may seem as an additional financial burden for the government. Nevertheless the real economic, environmental, and health costs of mismanagement of health care risk waste cannot be quantifiable.

The consequences of inadequate management of health care risk waste generated in homes are not limited to patients, their relatives, and health care workers but affects waste workers, 
scavengers, and the unsuspecting public. It contributes to the morbidity, mortality, and decreased in life expectancy especially for the poor and the vulnerable groups. It also contributes to environmental pollution and degradation.

\section{AUTHOR CONTRIBUTION}

This is the original work of the first author supervised by the second author.

\section{FUNDING}

This study was funded by University of South Africa and Mangosuthu University of Technology.

\section{ACKNOWLEDGMENT}

The authors will like to thank the Department of Health for their involvement in the study

\section{CONFLICT OF INTEREST}

No conflict of interests to be declared.

\section{REFERENCES}

[1] Hossain, S.; Santhanam, A.; Norulaini, N.A.N.; Omar, A.K.M. Clinical solid waste management practices and its impact on human health and environment - A review. Waste Management. 2011; 31(4), 754-766. Available from https://www.ncbi.nlm.nih.gov (Accessed on 01 June 2015).

[2] Phorano, O.M., Nthomang, K., \& Ngwenya, B.N. HIV/AIDS, Home care and human waste disposal in Botswana. African Journal. 2005; 37(1), 161-178. Available from http://www.sabinet.co.ca [Accessed 11 August 2015].

[3] Kang'ethe, S. Clinical waste management in the context of the Kanye community home based care programme. Botswana. African Journal of Aids Research. 2008; 7(2), 187-194. Available from: https://www.ncbi.nlm.nih.gov (Accessed on 11 August 2015).

[4] Hangulu, L.; Akintola, O. Health care waste management in community-based care: Experiences of community health workers in low resource communities in South Africa. BMC Public Health. 2017; 17(5), 12889-14378. Available from https://www.ncbi.nlm.nih.gov (Accessed on 14 June 2017).

[5] Miyazaki, M.; Imatoh, T.; Une, H. The treatment of infectious waste arising from home health and medical care services: Present situation in Japan. Waste Management. 2007; 27(1), 130-134. Available from https://www.sciencedirect.com (Accessed on 15 May 2015).

[6] Ikeda, Y. Importance of patient education on home medical care waste disposal in Japan. Waste Management. 2014; 34(7), 1330-1334. Available from http://www.sciencedirect.com [Accessed 01 June 2015].

[7] Markkanen, P., Galligan, C., Laramie, A., Fisher, J., Sama, S. \& Quinn, M. Understanding sharps Injuries in Home healthcare: The safe home care qualitative methods study to identify pathways for injury prevention. BMC Public Health. 2015; 15(359), 1-12. Available from: https://www.ncbi.nlm.nih.gov [Accessed 14 July 2016].

[8] Shepperd, S.; Doll, H.; Broad, J.; Gladman, J.; Iliffe, S.; Langhorne, P.; Richards, S.; Martin, F.; Harris, R. Hospital at home early discharge. The Cochrane Database of Systematic Reviews. 2009; 21(1), 1-112. Available from https://www.ncbi.nlm.nih.gov (Accessed on 26 August 2016).

[9] Subratty, A.H. \& Nathire, H.M.E. A survey on home generated medical waste in Mauritius. International Journal of Environmental Health Research. 2010; 15(1), 45-52. Available from https://www.ncbi.nlm.nih.gov [Accessed 24 January 2015].

[10] Mabusela, M.D. An investigation of the challenges and coping mechanisms of home-based care givers for patients living with HIV in Mamelodi. Master of Art Dissertation. Pretoria: University of South Africa. 2010
[11] Masquillier, C., Wouters, E., Mortelmans, D., Van Wyk B., Hausler H. \& Van Damme, W. HIV/Aids competent households: Interaction between a health-enabling environment and community-based treatment adherence support for people living with HIV/Aids in South Africa. Public Library of Science One. 2016; 11(3), 1-19. Available from https://www.ncbi.nlm.nih.gov [Assessed 14 July 2016].

[12] Polivka, B.J.; Wills, C.E.; Darragh, A.; Lavender, S.; Sommerich, C.; Stredney, D. Environmental health and safety hazards experienced by home health care providers: A room-by-room analysis. Workplace Health \& Safety. 2015; 63(11), 512-522. Available from https://www.ncbi.nlm.nih.gov (Assessed on 20 November 2016).

[13] Komilis, D., Fouki, A. \& Papadopoulos, D. (2012). Hazardous medical waste generation rates of different categories of health-care facilities. Waste Management. 32(7), 1434- 1441. Available from: https://www.ncbi.nlm.nih.gov [Accessed 11 February 2012].

[14] World Health Organisation (WHO). Health-care waste management: Rapid assessment tool for country level. Geneva, Switzerland. 2001. Available from: www.who.int [Accessed 29 August 2013].

[15] South Africa. National Environmental Management Waste Act 59 of 2008. Pretoria.

[16] Rutala, W. \& Mayhall, G. Medical waste. Infection Control and Hospital Epidemiology. 1992; 13(1), 38-48. Available from https://www.shea-online.org [Accessed 06 May 2015].

[17] Jang, Y.C. Infectious/medical hospital waste: General characteristics in South Korea. Earth System and Environmental Sciences, Encyclopedia of Environmental Health. 2011; 227-231. Available from: https://www.ncbi.nlm.nih.gov [Accessed 11 August 2015].

[18] Hassan, M.M., Ahmed, S.A., Rahman K.A. \& Biswas, T.K. (2008). Patterns of medical waste management: Existing scenario in Dhaka City, Bangladesh. BMC Public Health. 2008; 8 (36), 1471-2558. Available from https://www.ncbi.nlm.nih.gov [Accessed 22 February 2013].

[19] Blenkharn, J.I. Clinical Waste Management. Encyclopedia of Environmental Health. 2011; 716-731. Available from http://www.sciencedirect.com. [Accessed 15 May 2015].

[20] Ngari, W.N. Assessment of management of health-care waste in non-government health care facilities in Nairobi Province. Master of Public Health. Kenya: University of Nairobi. 2009

[21] Udofia, E.A., Gulis, G. \& Fobil, J. Solid medical waste: A cross sectional study of household disposal practices and reported harm in Southern Ghana. BMC Public Health. 2017; 17(464), 1-12. Available from https://bmcpublichealth.biomedcentral.com [Accessed 4 July 2017].

[22] Mieh, T.M.; Iwelunmor, J; Airhihenbuwa, C.O. Resilience in home-based caregivers in Limpopo, South Africa. Journal of Health Care for the Poor Underserved 2013; 24(2), 697-705. Available from https://www.ncbi.nlm.nih.gov/pubmed/23728037 (Accessed on 28 February 2013).

[23] Loeliger, K.B.; Niccolai, L.M.; Mtungwa, L.N.; Moll, A.; Shenoi, S.V. "I Have to Push Him with a Wheelbarrow to the Clinic": Community Health Workers' Roles, Needs, and Strategies to Improve HIV Care in Rural South Africa. AIDS Patient Care and STDs. 2016, 30(8):385-394.doi:10.1089/apc.2016.0096. (Accessed on 24 August 2016).

[24] Ikeda, Y. Current status of home medical care waste collection by nurses in Japan. Journal of the Air \& Waste Management Association. 2017; 67(2) 139-143. Available from https://www.ncbi.nlm.nih.gov [Accessed 12 April 2017].

[25] Makhura, R.R. Knowledge and practices of health care workers on medical waste disposal in Mapulaneng Hospital in the Ehlanzeni District of South Africa. Master of Public Health. Limpompo: University of Limpompo. 2016

[26] Maseko, Q. Critical evaluation of medical waste management policies, processes and practices in selected rural hospitals in the Eastern Cape. Master of Social Science Dissertation. Grahamstown: Rhodes University. 2013.

[27] Ngeleka, P.S. An investigation into solid waste management in townships: The case study of Clermont, Kwa-Zulu Natal. Master of Science. Durban: University of KwaZulu-Natal. 2010.

[28] Naidoo, K. (2009). An analysis of municipal solid waste management in South Africa using the Msunduzi Municipality as a case study. Master of Science. Pietermaritzburg: University of Natal. 
[29] Cruvinel, V.; Ramos, H.; Galato, D. The impact of medical waste for human health and the environment. Proceedings of the International Conference on Waste Technology \& Management. Philadelphia, USA. 3-6 April 2016. Environment Complete: 2016; 866-877. Available from www.ebscohost.com. (Accessed on 20 November 2016).

[30] Selin, E. Solid waste management and health effects: A qualitative study on awareness of risks and environmentally significant behaviour in Mutomo, Kenya. Bachelor of Science in Environmental Health thesis. Kenya: Umea University. 2013.

[31] Kuchibanda, K. \& Mayo, A.W. Public health risks from mismanagement of healthcare wastes in Shinyanga Municipality Health Facilities, Tanzania. The Scientific World Journal. 2015 (981756), 1-11. Available from https://www.hindawi.com [Accessed 13 October 2016].

[32] Gold, K. Analysis: The impact of needle, syringe, and lancet disposal on the community. Journal of Diabetes Science and Technology. 2011; 5(4), 848-850. Available from https://www.ncbi.nlm.nih.gov [Accessed 14 July 2016].

[33] Chartier, G.; Emmanuel, J.; Pieper, U.; Prüss, A.; Rushbrook, P.; Stringer, R.; Townsend, W.; Wilburn, S.; Zghondi, R. Safe management of wastes from health-care activities. (2nd ed.) 2014. World Health Organisation. Geneva. Available from www.searo.who.int. (Accessed on 12 August 2015).

[34] World Health Organisation (WHO). Wastes from health-care activities. Fact sheet No. 253. Geneva, Switzerland. Geneva, Switzerland. 2009. Available from: www.who.int [Accessed 29 August 2013].

[35] Bothma, B. Waste pickers in South Africa. eNCA. 2014. Available from www.google.co.za. [Accessed 27 July 2015].

[36] Anindo, M., Jayaprakash, S., Gautam, R. \& Sadishkumar, K. Improper sharp disposal practices among diabetes patients in home care settings: Need for concern? Indian Journal of Endocrinology and Metabolism. 2015; 19(3), 420-425. Available from http://www.ebscohost.com. [Accessed 14 December 2017].

[37] Batalion, N. Rise in medical waste - an increasing global crisis. Health Talks. 2011. Available from http://www.healingtalks.com/newsletter. [Accessed 15 May 2015].

[38] Padayachee, K. \& Mohale, B. Children find dumped foetus. The Mercury. 2011. Available from www.google.co.za [Accessed 27 July 2015].

[39] Health Professions Council of South Africa (HPCSA). Guidelines for the management of health care waste. Pretoria. 2008.

[40] Van der Merwe, M., Lombard, J., Lombard, R., Lombard, R. Greening Durban. Lombard \& Associates. Sustainable Waste Management. Durban. 2009. Available from http://www.google.co.za [Accessed 10 December 2014].

[41] Alves, S., Souza, A., Tipple, A., Rezende, K., Rezende, F. \& Rodrigues, E. (2012). Management of waste generated in home care by the Family Health Strategy. Revista Brasileira De Enfermagem. 65(1), 128-134. Available from http://www.sciencedirect.com. [Accessed 15 May 2015].

[42] Olorunfemi, A.E., Elijah, O.O., Albert S.O. \& Alausa, O.K.O. HIV/Aids related home based care practices among primary health care workers in Ogun state, Nigeria. Health Services Research. 2012; 12(112), 1-6. Available from https://www.ncbi.nlm.nih.gov [Accessed 21 August 2015].

[43] Department of Environmental Affairs and Tourism. National waste information baseline report. Pretoria. 2012.

[44] Nkosi, Z. (2014) Narrowing the health gap for greater equity in health outcomes: The discourse around the NHI system in South Africa. Pretoria: University of South Africa. 2014.

[45] Fischer, T. Durban Climate Change Strategy Introductory Report Theme Waste and Air Pollution. Environmental Planning and Climate Protection Department. Durban. 2013. Available from http://www.durban.gov.za [Accessed 10 March 2016].

[46] Mosia, M.A. Feasibility of a healthcare waste management strategy in Soshanguve. Master Technologiae Dissertation. Pretoria: Tshwane University of Technology. 2006

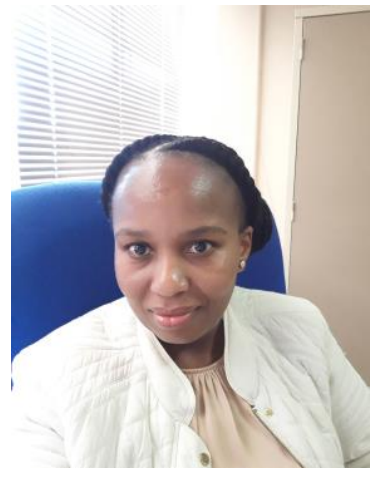

Thobile Zikhathile is a student at University of South Africa (UNISA, studying Master of Science in Environmental Science. Her research is on health care risk waste generated by home-based care givers. Her area of interest in research is home-based care and health care risk waste (generation, management, and the impact on health and environment). 